\title{
Strategies used to manage climatic risk: Lessons from farmers with expertise in dryland farming
}

\author{
D.I. GRAY, P.D. KEMP, P.R. KENYON, S.T. MORRIS, I.M. BROOKES, C. MATTHEW and M. OSBORNE \\ Massey University, Private Bag 11 222, Palmerston North, New Zealand \\ D.I.Gray@massey.ac.nz
}

\begin{abstract}
The management practices used by two brothers on their high performing summer-dry semi-finishing sheep and cattle farm were investigated over $21 / 2$ years (20062008). The study highlighted that in a dryland environment, the farmers designed their system to cope with both climatic variability and market risk. To reduce production risk, the farmers have strategies that increase feed supply over the summer - autumn, and transfer feed from the spring to the summer, autumn and winter periods. Their strategies are designed to significantly reduce feed demand over the summer - autumn, protect capital stock live weights and ensure adequate pasture cover levels at lambing. To reduce market risk, the farmers have strategies that allow the bulk of stock to be sold prime and in periods when most other farmers are not selling stock. An important element of their market risk strategy is the generation of adequate stocks of feed reserves that can be used to delay stock sales in a drought until markets improve.
\end{abstract}

Keywords: management strategies, production risk, market risk, decision making, drought

\section{Background}

Climate change research has suggested that farmers will face increasingly variable climatic conditions in the future (Kenny \& O'Brien 2007). Central to the future survival of farming businesses in New Zealand is the ability to design and manage farming systems that can cope with climatic variability (Crawford et al. 2007). However, little has been published in the literature about how farmers design and manage their farming systems. Farmers who operate in dryland environments have considerable experience in managing climatic risk. Within this group, are individuals who are recognised as particularly good dryland managers. If the management "expertise" of these farmers was captured, it could then be passed onto others to help them better manage climatic variability. This paper describes the management practices of two brothers who are considered to have expertise in dryland management.

\section{Approach}

A single-case study design (Yin 2002) was used to investigate the decision making processes used by a sheep and cattle farmer who achieved levels of physical and financial performance that were consistently in the top $10 \%$ for his land class. An experienced farm management consultant was asked to identify a farmer whom he believed had expertise in dryland management. The criteria for selection were that the farmer consistently outperformed others in his district in terms of productivity and profitability. Semi-structured interviews and field observations (Gray 2001) were used to collect data on the case farmer's decisions over $21 / 2$ years (2006-2007 and 2007-2008). Interviews were taped, transcribed verbatim (Denzin 1989) and then the transcripts were analysed in-depth using qualitative data analysis (Dey 1993; Miles \& Huberman 1994). Management practices critical to achieving high performance were derived from the data, verified with the farmer and then compared with the literature. This paper describes how a farmer (in this case two brothers) with expertise in dryland management integrates a range of risk management strategies into his production system to cope with climatic variability.

\section{Results \\ Property and context description}

The farm, located $15 \mathrm{~km}$ east of Carterton in the Wairarapa, is operated by two brothers in partnership and has a 30 year average rainfall of $901 \mathrm{~mm} /$ annum (range $548-1297 \mathrm{~mm}$ ). The property is 985 effective hectares, of which two thirds is flat to gently rolling and a further third, rolling to steep hill country. The farm has a 41 ha block that is irrigated from the river over summer. The property is classified as semi-finishing and normally winters 4800 ewes, 1200 ewe hoggets, 700 R1yr and 400 R2yr bulls. Production and profitability benchmarking rank the farm in the top $10 \%$ for its class. For the period 2001 to 2006, the farm averaged $178 \%$ scanning and $137 \%$ lambing. In the year prior to the study the farm achieved $192 \%$ scanning and $155 \%$ lambing. Post-drought, the farm achieved a scanning percentage of $167 \%$ and a lambing percentage to docking of $146 \%$ in 2007 and scanned $164 \%$ in 2008 .

The first year of the study, 2006, was a cool, wet year with the third highest rainfall on record (Fig. 1). As a result of this, pasture growth rates were above average through the summer and autumn of 2006 (Fig. 2) and this is reflected in above average pasture cover levels for this period (Fig. 3). As a consequence of these conditions, 
Figure 1 Monthly rainfall data for the case farm.

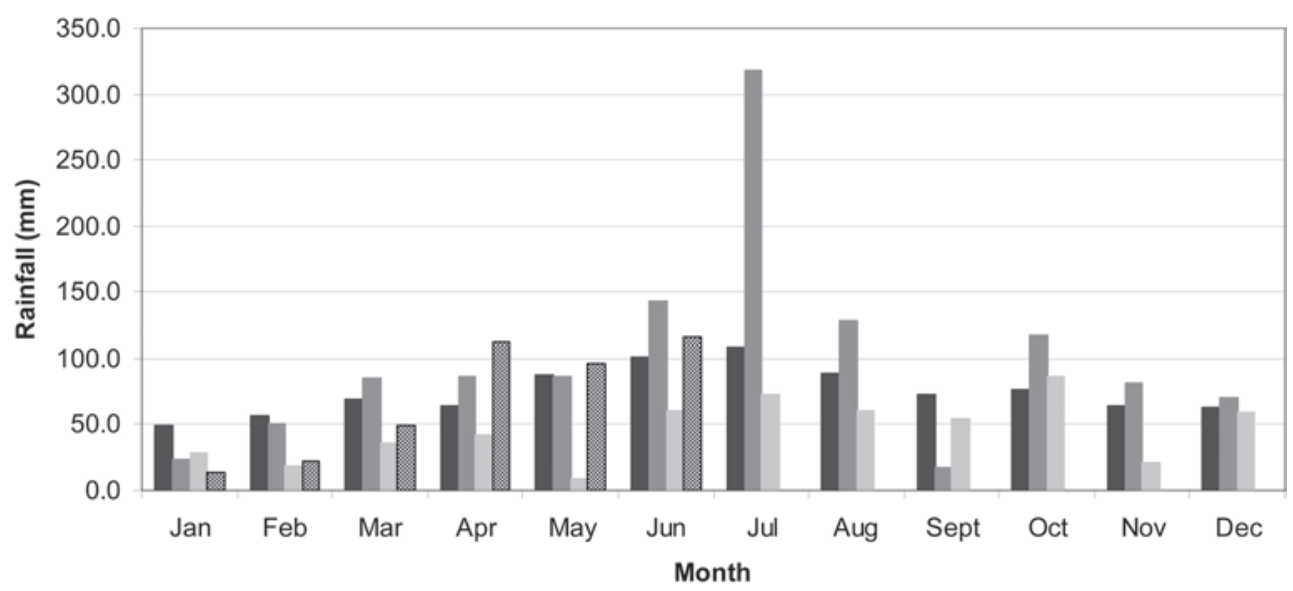

$30 \mathrm{yr}$ mean $=2006$ = 2007 뜸 2008

Figure 2 Monthly pasture growth rate data for the case farm.

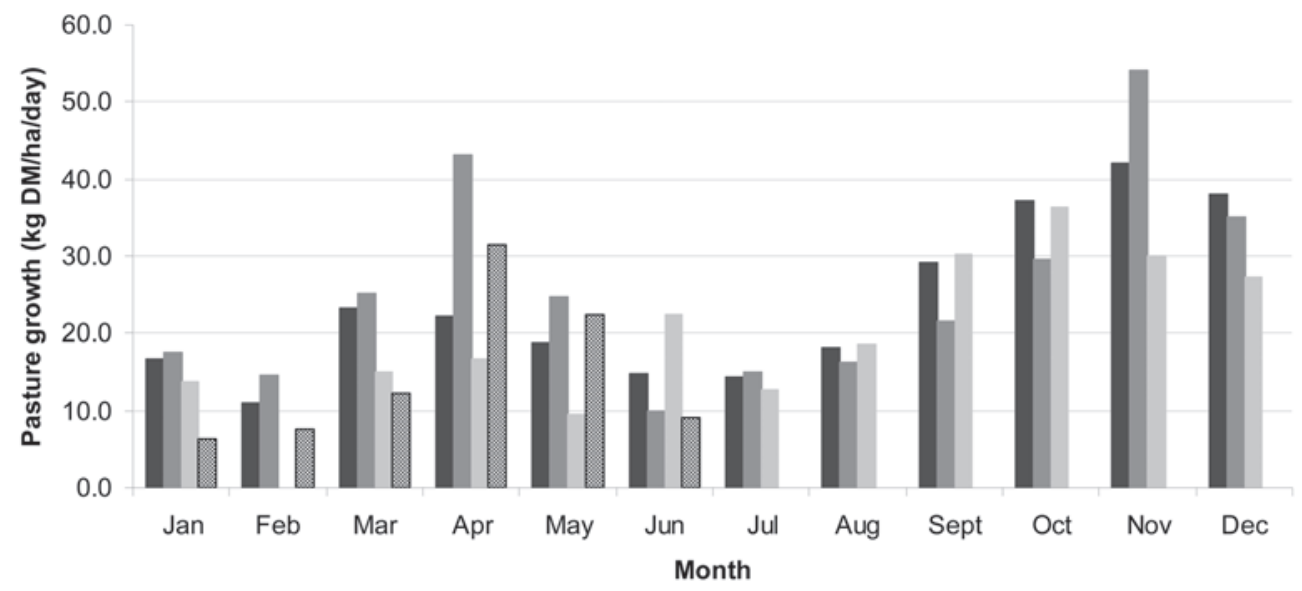

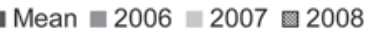

stock feed demand over this period (Fig. 4) was the highest for the 3 years of the study. The 2006 winter was cool and wet and the spring, with the exception of September, was similar (Fig. 1). As such, pasture growth rates (Fig. 2) were below average for most of the spring until soil temperatures improved in November. This is reflected in the average pasture cover (Fig. 3) and feed demand figures (Fig. 4) that were below average until November.

Low rainfall through the summer and autumn of 2007 (Fig. 1) resulted in a "late drought" with below average pasture growth rates (Fig. 2) from January until May. Pasture cover levels declined from above average levels in January, a consequence of the wet 2006 spring, to $1000 \mathrm{~kg} \mathrm{DM} / \mathrm{ha}$ at the end of June (Fig. 3). The drought broke in June, but rainfall was below average through winter and most of the spring and this resulted in the onset of an early drought in the spring of 2007 (Fig. 1). The annual rainfall through 2007 was $548 \mathrm{~mm}$ (1998 drought $-693 \mathrm{~mm}$ ), the lowest recorded over the last 30 years.

Over the winter and spring of 2007, pasture growth rates were similar to average until November when low soil moisture levels reduced pasture growth through November and December (Fig. 2). Because average pasture cover was low going into winter, pasture cover levels for the 2007 spring were below average in every month, particularly in late spring (Fig. 3). Feed demand was below average through winter and early spring as a consequence of low pasture cover levels (Fig. 4). As pasture cover levels improved, feed demand exceeded the average over September, October. However, feed 
Figure 3 Average pasture cover data for the case farm.

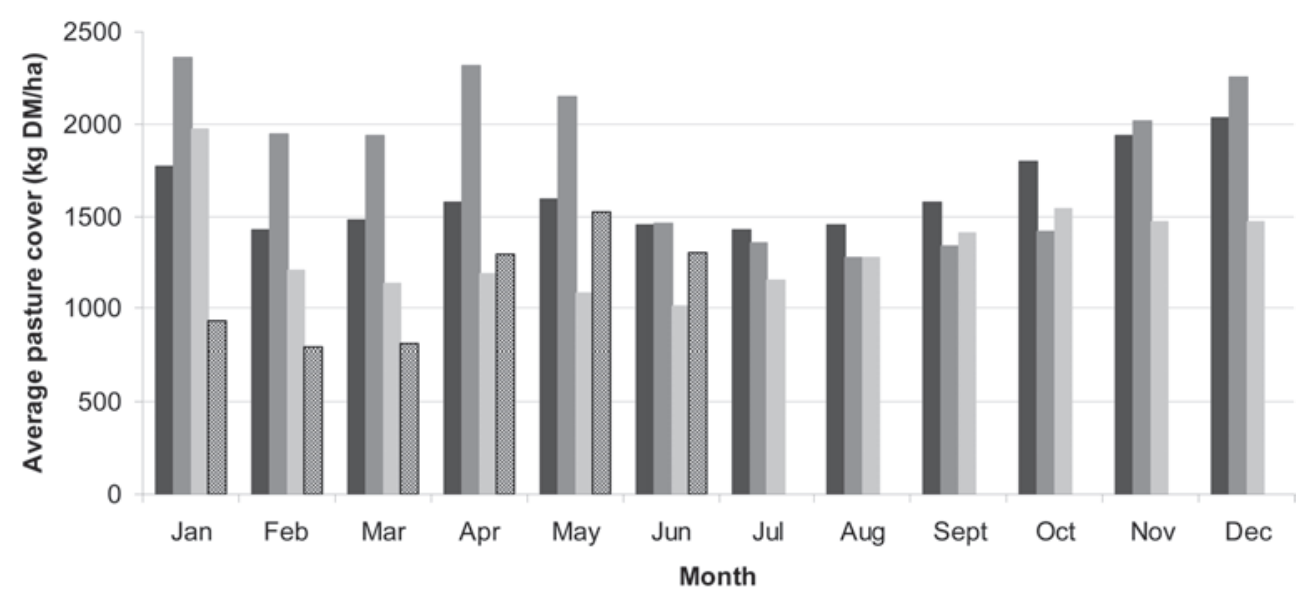

घ Mean $\| 2006=2007 \square 2008$

Figure 4 Monthly feed demand data for the case farm.

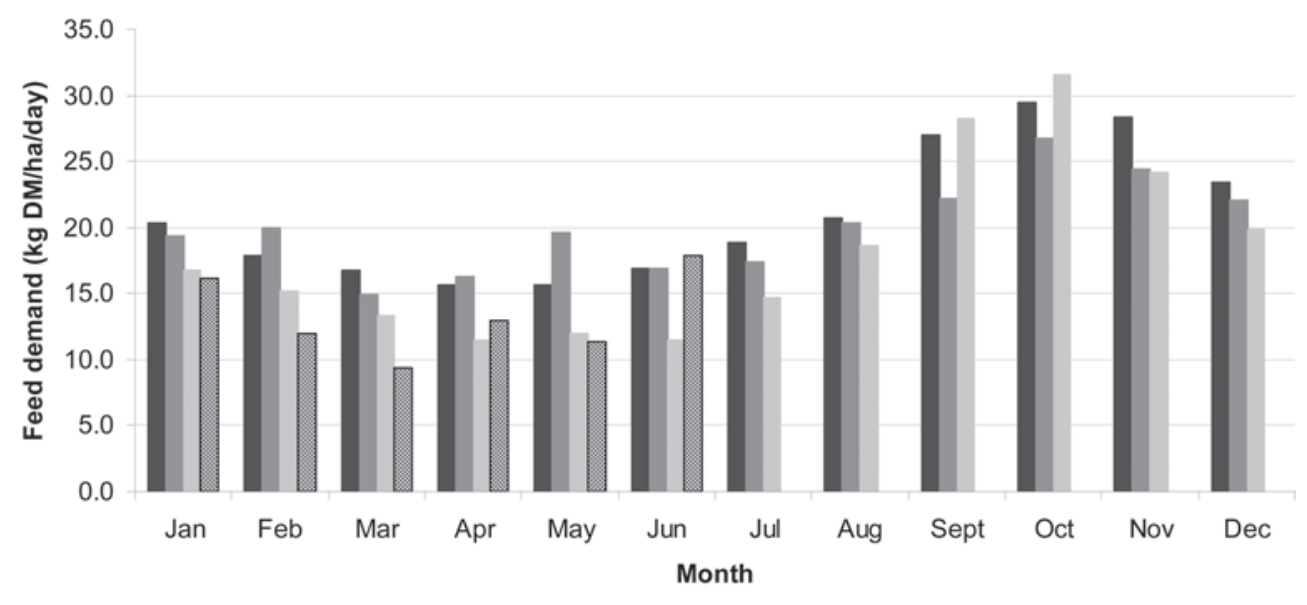

Mean $\square 2006=2007 \approx 2008$

demand was reduced to below average levels in November, December in response to the dry conditions.

The dry conditions over the spring of 2007 were exacerbated with below average rainfall from January until March 2008 (Fig. 1). As a consequence, pasture growth rates were considerably below average over the summer of 2008 and average pasture cover levels fell to $795 \mathrm{~kg} \mathrm{DM} / \mathrm{ha}$ at the end of February (Fig. 3). Feed demand over the period January to March was the lowest for the three years of the study (Fig. 4). In April, the drought broke with above average rainfall through April and May (Fig. 1). This resulted in above average pasture growth rates over this period, which increased average pasture cover to $1527 \mathrm{~kg} \mathrm{DM} /$ ha by the end of May.

\section{Dryland management strategies and tactics}

Preliminary analysis has identified that, although drought is important in terms of production risk, it is also critical in terms of market risk, both for product and feed input prices. Although the risk literature (Martin 1994, 1996) identifies a range of strategies farmers can and do use to manage production risk, little is reported on the effectiveness of such strategies or how they are best integrated into a farming system. To manage these risks, the farmers have made a range of strategic decisions in relation to the design of their production system. These decisions can be classified into three types: (1) feed supply, (2) feed demand and (3) marketing decisions. The farmers use an intensive monitoring system and tactical decisions to modify 
these strategies to cope with the specific conditions in any one year.

\section{Feed supply}

A key focus of the farmers' strategy is to make the most out of the reliable pasture growth that occurs over spring in the Wairarapa (McLaren 1993). Although summer and autumn pasture growth rates are highly variable, the spring is relatively consistent and on average, $50 \%$ of annual pasture production occurs between September and December. Therefore, the farmers aim to optimise ewe, lamb and cattle growth rates over this period. To ensure optimum spring growth, the farmers aim for sward heights of 5-6 $\mathrm{cm}(1400-1500 \mathrm{~kg} \mathrm{DM} / \mathrm{ha})^{1}$ at lambing (7 August). Nitrogen, applied in April, May (100 - $240 \mathrm{ha})$ and late winter (155 - $300 \mathrm{ha})$ at between $23-46 \mathrm{~kg} \mathrm{~N} / \mathrm{ha}$, self-feeding silage (250 wet tonnes), hay (200 large bales) and winter forage crops ( $\approx 40 \mathrm{ha}$ ) are used to increase feed supply over winter to ensure target pasture cover levels are met at lambing. The selffeeding silage, forage crops and hay feed $600 \mathrm{R} 1 \mathrm{yr}$ bulls and 250 R2yr bulls from June until early September.

Tactically, the farmers will adjust the area and the rate of nitrogen in response to average pasture cover levels in autumn and late winter. For example, in the autumn of 2006 when pasture cover levels were over $1900 \mathrm{~kg} \mathrm{DM} / \mathrm{ha}$, the farmers only applied nitrogen to 100 ha at a rate of $36.8 \mathrm{~kg}$ $\mathrm{N} /$ ha. In contrast, in 2007 when pasture cover levels in autumn were less than $1200 \mathrm{~kg} \mathrm{DM} / \mathrm{ha}$, the farmers applied nitrogen to 240 ha at $36.8 \mathrm{~kg} \mathrm{~N} / \mathrm{ha}$. Similarly, the use of the forage crops and the self-feeding silage may be adjusted in response to pasture cover levels. In a spring where pasture cover levels are above average, the bulls will be taken off the silage and/or forage crops early to ensure pasture quality is maintained. In contrast, in a cold wet spring such as in 2006 where pasture cover levels were below target, half of the R1yr bulls remained on the forage crops for $2-3$ weeks longer than normal and their diet was supplemented with additional hay and balage. In 2007, when pasture cover levels were below target due to the flow-on effects of the drought, the R1yr bulls were also retained on the forage crops until late September.

The control of pasture quality is critical on summerdry farms. The farmers aim to have pasture cover at or below $2250 \mathrm{~kg} \mathrm{DM} / \mathrm{ha}^{2}(\approx 5 \mathrm{~cm})$ at the end of December after silage has been removed. To help control the spring flush, feed supply is reduced over the late spring by making supplements and planting forage crops. The farmers plant around 40 ha of winter forage and 40 ha of summer forage crops in October. Silage $(\approx 35 \mathrm{ha})$ is made in November with balage $(\approx 10$ ha) and hay $(\approx 10$ ha) made in December and January respectively. These decisions effectively remove $350 \mathrm{~kg} \mathrm{DM} / \mathrm{ha}$ from the system and transfer feed from a period of surplus in late spring to periods of deficit in summer or winter. Tactically, feed supply in late spring is adjusted primarily through the area of silage that is made. In a poor growing year such as 2007 , area is taken off the R2yr bulls and nitrogen is applied to the silage area to ensure a minimum of 500 wet tonnes is harvested. In that year, the farmers also purchased an additional 250 wet tonnes of silage because they believed, on the basis of their rainfall records, that they were moving into drought conditions. In good growing years, additional silage is made so that additional reserves can be set aside for a drought. In the winter of 2006, the farmers had reserves of 2000 wet tonnes of silage on-hand that had accumulated since the last major drought in 1998.

To reduce the impact of the summer feed deficit, the farmers irrigate 41 ha, graze 40 ha of summer forage crops and feed out around 15 tonnes of barley. Irrigation ensures continuity of feed supply on the 41 ha of river flats from March to December and the farmers apply two dressings of $20 \mathrm{~kg} \mathrm{~N} / \mathrm{ha}$ in January and February to further increase feed supply on this block. The additional feed grown as a result of the irrigation increases the average pasture growth rates over the whole farm by 2 $3 \mathrm{~kg} \mathrm{DM} /$ ha/day. However, in extreme droughts, because the irrigation system draws on river water, water supply may be cut off because of inadequate riverflows such as occurred in 2008. Typically the irrigated area is used to finish the heavier bulls and trade lambs. In 2008, however, the farmers used part of the irrigation block to preferentially feed the lighter ewe lambs and two tooths to ensure they met target live weights at breeding.

Tactically, the farmers manipulate summer feed supply by changing the date at which the irrigation system is turned on and off. For example, the irrigation system was not turned on until mid January 2007 because rainfall (Fig. 1) and pasture cover levels (Fig. 3) were above average over late spring. However, the irrigation was used through until the end of April because of below average rainfall through summer and autumn (Fig. 1). In contrast to 2006/07, the irrigation system was turned on in late November in 2007 in response to low soil moisture levels after a dry winter and spring (Fig. 1). However, in response to above average rainfall in April 2008, the irrigation system was turned off .

Barley ( $\approx 15$ tonnes) is normally fed to the two tooths and thin MA ewes from 6 weeks prior to breeding until 2 weeks after the start of breeding at $100 \mathrm{~g} /$ ewe/day to improve ovulation rates. The amount of barley that is fed to the ewes is adjusted tactically in response to feed supply and also pasture quality. For example, in 2008,

${ }^{1}$ Winter calibration. ${ }^{2}$ Late spring pasture calibration. 
the farmers fed 40 tonnes of barley to all the ewes over an 8 week period because pasture cover levels were around $800 \mathrm{~kg} \mathrm{DM} / \mathrm{ha}$ (Fig. 3). In other years, if feed levels are adequate and the live weight of the MA ewes is ahead of target, the farmers may only feed barley to the two tooth ewes, reducing the amount of barley used to around 10 tonnes.

Summer forage crops are used to ensure good weight gains in the replacement ewe lambs and ewe hoggets. The ewe hoggets and their lambs are grazed on leaf turnips pre-weaning. After weaning, the hoggets either go onto the best dryland feed, irrigated pasture or onto a forage crop to ensure that they reach target two-tooth live weights at breeding. The replacement ewe lambs are also grazed on leaf turnips post-weaning. The medium weight-range trade lambs are grazed on the summer forage crops (leaf turnips and rape) and then the heavier animals of this mob go onto the irrigated area for finishing. Tactically, there is little the farmers can do to adjust the feed supply from the summer forage crops. However, they do graze the winter forage crops in March and April with the ewe lambs to increase feed supply and this occurred in both the autumn of 2007 and 2008 in response to drought conditions. To reduce the impact of the grazing on final winter forage crop yield, the farmers apply urea $(100 \mathrm{~kg} /$ ha) to the crops post-grazing.

In a normal year, with the summer forage crops and barley, pasture growth is sufficient to meet feed demand and silage is not fed out over this period. For example, in 2006 , because of the high pasture cover levels through the autumn (Fig. 3), no silage was fed out. In contrast, in 2007 , the farmers fed approximately 1500 wet tonnes of silage to the ewes and a proportion of the 18 month bulls from early March until the end of June because the farm was in drought conditions. In 2008, 750 wet tonnes of silage was fed to the ewes and 18 month bulls from mid February until mid May. The silage $(\mathrm{ME}=10.0 \mathrm{MJ} \mathrm{ME} /$ $\mathrm{kg} \mathrm{DM}$ ) is used primarily to maintain ewe live weight and condition over the summer - autumn to ensure good ovulation and conception rates. The use of silage as a summer supplement has been shown to increase ewe ovulation rates, particularly where high quality silage is used (Hayman \& Munro 1983; Rattray 1983). Silage is only fed to the 18 month bulls if there is inadequate pasture cover to maintain live weight.

\section{Feed demand}

The farmers make a number of important decisions that influence feed demand over the year and these are critical for the successful management of a dryland system. The choice of stocking rate, lambing date and weaning date are major determinants of the pattern of feed demand and how well it matches the annual pattern of pasture growth (Kerr 2000). The farmers, in conjunction with their consultant, estimate pasture growth rates from animal performance and pasture cover data. They have 9 years of pasture growth rate data and draw on this information and their experience to make these strategic decisions. The farm winters around $12.2 \mathrm{su} / \mathrm{ha}$, lambing in early August and normally weaning at the end of November (mean 105 days to weaning). The combination of stocking rate and lambing date is designed to ensure that there is adequate feed for high sheep performance whilst still controlling pasture quality. It is also designed to ensure that the majority of lambs and all R2yr bulls can be finished in most years.

The lambing date is designed to coincide with the spring flush and ensure that a large proportion $(\approx 50 \%)$ of lambs can be finished off the dam at weaning prior to the summer dry. These lambs normally average between 14.5 and 15.5 $\mathrm{kg}$ carcass weight. Lambing date is not set any earlier because in some years it is difficult to provide adequate feed over early lactation, particularly after a drought in the previous summer. With a mean lambing date of around the 17 August, there is a only a 2 week period for most of the ewe flock post-lambing before pasture growth rates increase from 18 $\mathrm{kg} \mathrm{DM} / \mathrm{ha} /$ day to $29 \mathrm{~kg} \mathrm{DM} / \mathrm{ha} /$ day, which reduces the risk of ewes and lambs being under-fed post-drought. The risk literature (Martin 1994) identifies long-term flexibility as a means of coping with risk, but does not link this to specific decisions such as the choice of stocking rate and lambing date.

The choice of sheep:cattle ratio and cattle policy has an important influence on the pattern of feed demand. The farmers run a high ratio of cattle ( $>40 \%)$ to sheep because it is important for animal health and pasture quality reasons. However, more importantly, the cattle also act as a "buffer" and allow the farmers to protect the live weight of their breeding flock in the face of a variable feed supply (Harvie 1989). To allow this level of flexibility, the farmers have adopted a 2-year bull beef policy and run a high proportion of trading cattle $(>40 \%)$. With this policy, the cattle do not need to achieve high rates of live weight gain throughout their time on the farm. In periods when feed is short, they can be placed on sub-optimal or maintenance feeding levels. McRae (2003) noted that selling bulls as 2-year olds provided greater flexibility and better control of pasture quality than that achieved in an 18-month policy. He reported that, although such a policy reduced technical efficiency, it improved economic efficiency because the older bulls were sold at higher prices per kilogram.

To control pasture quality, the farmers aim to have pasture cover at or below $2250 \mathrm{~kg} \mathrm{DM} / \mathrm{ha}^{3}(\approx 5 \mathrm{~cm})$ at

\footnotetext{
${ }^{3}$ Late spring pasture calibration.
} 
the end of December. Spring feed demand is increased dramatically by removing $600 \mathrm{R} 1 \mathrm{yr}$ bulls from winter forage crops and $250 \mathrm{R} 2 \mathrm{yr}$ bulls from self-feeding silage in early September and set stocking them with the sheep, effectively increasing the stocking rate on pasture by 4.5 $\mathrm{su} / \mathrm{ha}$. The farmers also increase spring feed demand by aiming for a high $(140-160 \%)$ lambing percentage and lambing their ewe hoggets. To achieve a high lambing percentage, the farmers aim to have their ewe hoggets, two-tooths and mixed-age ewes at live weights of $45 \mathrm{~kg}$, $60 \mathrm{~kg}$ and $65 \mathrm{~kg}$ respectively at breeding, another important strategic decision. Tactically, there is little the farmers can do to increase spring feed demand. In the past, they have removed the cattle off the winter forage crops and self-feeding silage early in years when early spring growth has been above average, but this did not happen over the study period.

The summer feed deficit is managed through a combination of techniques. Weaning and stock sales (lambs, cull ewes, R1yr and R2yr bulls) are scheduled to occur before Christmas to reduce feed demand, a policy commonly advocated in summer dry areas (Harvie 1989; Kinnell 1993; McLaren 1993). Feed demand is further reduced by delaying the purchase of the 700 replacement R1yr bulls until summer, autumn. The farmer normally weans at the end of November (mean 105 days to weaning). This reduces feed demand prior to the summer through the sale of around $50 \%$ of the lambs, a reduction in ewe intakes post-weaning and the sale of some 600 cull ewes (Fig. 4). Importantly, some 2200 lambs are drafted off the dam prior to weaning over the period late October to late November at a carcass weight of $14.5 \mathrm{~kg}$. This allows additional feed to be provided to the remaining ewes and lambs so that weaning can be delayed and additional lambs can be drafted off dam. During the preweaning drafting process, all the ewes are checked and culls identified so that the culling process is streamlined at weaning.

The prime determinant of weaning date is ewe live weight/condition, not average pasture cover. If the farmers believe that ewe live weight or condition is likely to fall in the next $1-2$ weeks because the quantity and quality of feed is inadequate, the ewes are weaned. The farmers aim to wean the ewes at, or close to their breeding live weight so that feed is not required over summer - autumn to increase ewe live weight. Tactically, the study highlights how weaning date can be manipulated in response to climatic conditions. In 2006, during a wet spring, the quantity and quality of feed on-hand was such that the farmers did not wean until mid to late December. In contrast, in the dry spring of 2007, the ewes were weaned mid November, 15 days earlier than normal.

A key target for the farmers is to have the ewes at or close to their breeding live weight at weaning because they know that it is difficult to put weight on ewes over the summer, autumn. To achieve these targets, the farmers aim to lamb onto a high average pasture cover (14 - 1500 $\mathrm{kg} \mathrm{DM} / \mathrm{ha}$ or $\approx 5-6 \mathrm{~cm}$ ) in early August and maintain sward height between $5-6 \mathrm{~cm}$ over lactation. They aim for this level of pasture cover because the bulls are set stocked with the sheep over lactation. Morris \& Kenyon (2004) reported that there was no advantage to lamb survival, weaning weight or ewe live weight and condition score gain in swards above $4 \mathrm{~cm}$. However, these results were from a sheep-only trial and did not investigate the effects of mixed cattle and sheep grazing over lactation.

Stock sales play an important role in reducing feed demand over summer. The farmers aim to wean as many prime lambs as possible off the ewes to reduce summer feed demand. To this end, ewes mated to a terminal sire (two-tooth and four-tooth ewes) are lambed onto the early country so that their lambs reach suitable weights by weaning. The farmers aim for sward heights of 5-6 $\mathrm{cm}(14-1500 \mathrm{~kg} \mathrm{DM} / \mathrm{ha})$ and good ewe condition at lambing ( $>2.5$ condition score) to ensure high levels of milk production, optimum lamb growth rates and high weaning weights $(28-30 \mathrm{~kg} \mathrm{LW})$. This allows a large proportion $(\approx 50 \%)$ of the lambs to be sold off dam at weaning and these lambs yield better than lambs sold after weaning (45\% versus 43\%). Muir et al. (1999) reported that high ewe milk production over lactation provided a small but significant advantage in lamb growth rates for high fecundity flocks which allowed the earlier drafting of lambs and early season premiums for both store and prime lambs. Conversely, Muir et al. (1999) found that lambs failing to reach minimum drafting weights were also penalised because of the prevailing drought conditions and low market prices. The high weaning weight is important for the rearing of good replacements and it also determines how quickly the remaining trade lambs can be finished.

Of the remaining trade lambs, 1000 are normally sold store at weaning and the remainder are normally finished from December to June at carcass weights of 15.0 - 15.5 $\mathrm{kg}$. The best lambs are placed on the irrigated area with medium lambs on the summer forage crops and the lighter lambs on dryland pasture. As lambs are finished on the irrigated area, the heavier lambs on the forage crops replace them and similarly, the better light lambs come onto the forage crops. Tactically, the farmers will wean and sell more lambs earlier to lighter weights or to the store market to reduce feed demand in a drought. In 2006, a wet spring, the farmers weaned in mid to late December and sold lambs at around $15.5 \mathrm{~kg}$ carcass weight. In contrast, in 2007, an early drought, the farmers weaned mid November and had sold half their lambs a month earlier and at $1.0-2.0 \mathrm{~kg}$ carcass weight lighter 
Figure 5 Bull liveweight data for the case farm.

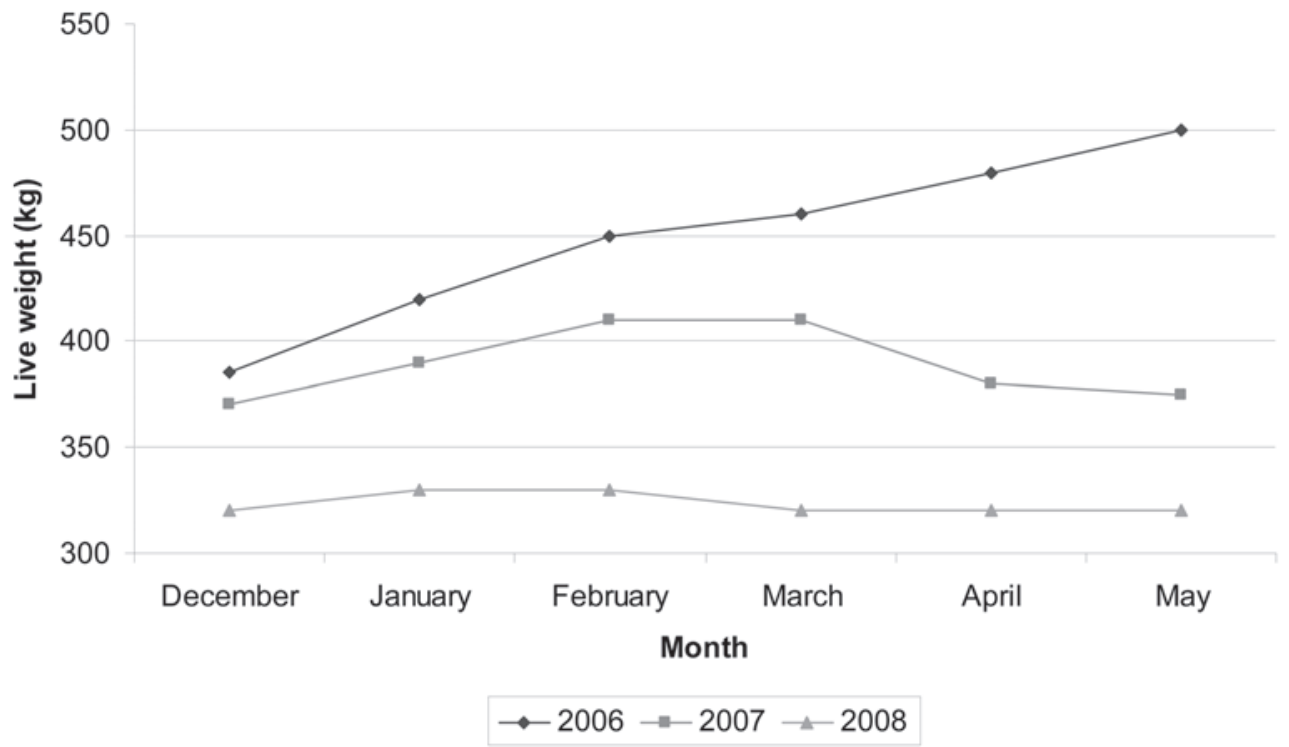

than in 2006. A thousand store lambs were also sold a month earlier and instead of finishing the hogget lambs as in 2006, half of these were sold store at the end of December further reducing feed demand.

The farmers aim to sell the $400 \mathrm{R} 2 \mathrm{yr}$ bulls at around $580 \mathrm{~kg}$ live weight or $300 \mathrm{~kg}$ carcass weight before Christmas to reduce summer feed demand. The better R2yr bulls are finished on the irrigated area whilst the remainder are run on the more improved sheep country, until space is available on the irrigated block. A mob of the heaviest $100 \mathrm{R} 1 \mathrm{yr}$ bulls are sold to techno-beef producers in late December to further reduce summer feed demand. Another 140 18-month bulls are sold between March and May to reduce winter feed demand. Tactically, the farmers adjust the sale dates and sale live weights of the bulls to manipulate feed demand. For example, in 2006 bulls were held for longer because of surplus feed in late spring. In contrast, in 2007, bulls were sold earlier and at lighter weights, down to $490 \mathrm{~kg}$ LW compared to the norm of around $580 \mathrm{~kg} \mathrm{LW}$, to reduce feed demand because of the dry conditions. In a drought, the intakes of the 700 younger bulls are restricted until feed conditions improve. Data in Figure 5 show the live weight profiles of these bulls for the summer - autumn of 2006, 2007 and 2008. In 2006, with adequate pasture cover levels through the summer and autumn, the bulls increased live weight from the end of December at $385 \mathrm{~kg} \mathrm{LW}$ to reach $500 \mathrm{~kg} \mathrm{LW}$ by the end of May. In contrast, the farmers restricted bull intakes over the autumn of 2007 as the late drought reduced feed supply and in 2008, bull intakes were restricted from late spring until the end of May. As a consequence, the live weight of the bulls going into winter were $125 \mathrm{~kg}$ and $180 \mathrm{~kg}$ lighter in 2007 and 2008 respectively, than in 2006 (Fig. 5). This meant that in both drought years, the 200 heaviest bulls were too light to slaughter pre-winter to reduce winter feed demand. In both years, the farmers decided to winter these cattle using their silage reserves rather than sell them on a weak store market.

Cattle purchase decisions are also used to manipulate feed demand. The farmers purchase their 700 replacement bulls in summer - autumn rather than over spring. This reduces late spring, early summer feed demand. Tactically, the date and timing of cattle purchases is a function of feed supply. For example, by the end of March 2007, the farmers had purchased more bulls (501 versus 448) than in 2006 which was a wetter summer - autumn. However, no further purchases were made from April to June in 2007 as the "late" drought took effect whereas in 2006 another 272 bulls were purchased over this period. In comparison, in March 2008, the year of the early drought, the farmers had only purchased 209 bulls.

The two-tooths and lighter MA ewes are priority stock over summer and are preferentially fed to ensure they reach good breeding weights. A few weeks prior to, and over breeding, the ewes are on daily shifts to ensure they at least hold condition over this period. Tactically, in extreme conditions, the ewe hoggets are not bred and this occurs if their live weight is below $38 \mathrm{~kg} \mathrm{LW}$ at 1 May. However, ewe breeding date is not adjusted in response to drought conditions, rather, the farmers use other contingencies to cope with reduced feed supply.

\section{Marketing}

Market risk is a major problem in summer dry areas because as feed supply declines farmers sell stock and 
prices fall dramatically. Conversely, the market price of feeds increases significantly as drought conditions develop. As such, the impact of market risk can be as devastating as that of production risk on a dryland farm. The farmers use most of the market risk management strategies (use of market information, spreading sales, diversification, and forward contracting) mentioned in the literature (Martin 1996) with the exception of futures markets. However, this study provides more in-depth information on market risk strategies. For example, to minimise the impact of market risk, the farmers aim to sell cattle outside of peak supply periods where possible. The R2yr bulls are sold between July and December when price premiums exist, something that can be done with a 2 -year policy. The more forward 18 -month bulls are either sold before Christmas on a buoyant store market $(\approx 100$ head $)$ or in autumn $(\approx 140$ head $)$ when prices are improving.

The farmers aim to sell $50 \%$ of their lambs prime prior to (late October - late November), and at weaning at the end of November to obtain a premium relative to later sales. Store lamb contracts are sought and these lambs are also sold at the end of November to obtain higher prices. The farmers aim to sell as many of the remaining lambs prime to avoid poor store prices over summer. A contract to sell 1000 lambs prime over summer is normally set up in the preceding spring to ensure works space is available. The lighter hogget lambs are retained over summer, and then finished over late autumn-early winter to obtain higher returns. The summer forage crops and irrigation allow the farmers to retain stock over a period when other farmers must sell due to feed limitations. To reduce market risk in terms of feed prices, the farmers have reserves of silage. They also buy in additional silage (up to 250 wet tonnes) and forward contract additional barley (up to 40 tonnes) in spring if they consider conditions are going to turn dry.

Tactically, the farmers intensively monitor the store and prime markets, continually looking for opportunities that might improve their margin. The current and expected future feed supply also play an important role in these decisions. Actual decisions about what, how many, and when to sell and at what live weight are based on the margin the farmers think they can make from the decision relative to alternative decisions given the expected future feed supply (Harvie 1989). For example, in December 2007, the farmers decided to retain all the hogget lambs on maintenance through the summer - autumn and finish them in early winter because the store market was weak and feed supply was adequate at that point in time. In contrast, in 2008, half the hogget lambs were sold at weaning because feed supply was declining rapidly due to the early onset of drought and the farmers had found a buyer who was willing to pay a premium for good quality hogget lambs. The large reserve of silage also plays an important role tactically. It allowed the farmers to retain their 18 month cattle through both the 2007 and 2008 droughts rather than selling them on rapidly declining store markets.

\section{Monitoring system}

The farmers monitor a wide range of factors in relation to feed supply for decision making purposes. They have 30 years of daily rainfall and soil temperature data and 9 years of average pasture cover, pasture growth rate, pasture quality ( $1-5$ score), feed demand, animal live weight and physical performance data. Data are monitored at regular intervals and compared to both forecasted targets set out in their feed plan and the historical data set. The farmers are looking to identify deviations from the plan's targets which will require the implementation of contingencies to minimise the impact of such deviations. Historical data is used to identify where conditions might be similar to a previous year and this information is used to extrapolate future likely conditions and determine the most suitable contingencies based on what actions they had undertaken under similar conditions in the past.

The farmers monitor daily, monthly, and cumulative rainfall and soil temperatures. This information, in conjunction with information from long-range forecasts and weather patterns (position, stability, wind direction) are used to infer likely future pasture growth rates. In the spring of 2007, the farmers inferred from the cumulative rainfall data and weather information that it was likely they would face an early drought and made a number of critical decisions (early weaning, initiation of the irrigation, early stock sales, the purchase of additional silage and barley) during November that helped mitigate the effect of the drought. Soil temperature and rainfall information is also used to help decide when to apply nitrogen and when to shut up silage.

Average pasture cover levels, pre- and post-grazing residuals, pasture quality, stock condition/live weight and behaviour are critical factors that are monitored by the farmers for making feeding decisions. For example, pasture cover, pasture growth and rainfall data are important determinants of when to initiate supplement feeding. In contrast, condition is the primary determinant of weaning date for the ewes. Average pasture cover levels, pre- and post-grazing residuals, condition/live weight and animal behaviour are important determinants of stock feeding decisions over winter. Importantly, the farmers manage the distribution of condition/live weight and pasture cover. As such, they do not just focus on the average live weight or pasture cover, but the distribution of this about the mean. For example, over summer, lighter ewes are preferentially fed and the intakes of better condition ewes are often reduced to allow this to happen. 
Similarly, over spring, when the ewes are set stocked, cattle mobs are shuffled to control paddocks that are too long or shifted out of paddocks that are falling below optimum levels.

The farmers intensively monitor markets during periods of the year when they are buying and selling stock. This includes schedule and store prices, the New Zealand dollar, and information from buyers. They are also monitoring the feed situation and markets across the country because feed availability in other regions can have a significant impact on the prices they receive for their stock. A problem with the last two droughts was that dry conditions occurred across much of New Zealand rather than just being isolated to the East coast. This had a much greater impact on markets than a more localised drought. The farmers' stock agents play an important role in the monitoring of markets and often identify opportunities that can be capitalised on.

\section{Conclusions}

This study has highlighted that in a dryland environment, farmers must design their systems to cope with both production and market risk.

To reduce production risk, the system must have strategies that:

1. Increase feed supply over the summer, autumn, and transfer feed from the spring to the summer - autumn and winter periods.

2. Significantly reduce feed demand over the summer - autumn.

3. Protect capital stock live weights and ensure adequate pasture cover levels at lambing.

To reduce market risk, the system must have strategies that:

1. Allow the sale of stock into periods when most other farmers are not selling stock.

2. Allow the bulk of stock to be finished rather than sold store.

3. Allow the purchase of stock during periods when other farmers are not buying stock.

4. Generate adequate stocks of feed reserves that can be used to delay stock sales in a drought until markets improve.

To cope with variation in feed supply within years, farmers need to be tactically astute. To do this, they need:

1. A sophisticated monitoring system that quickly identifies problems or opportunities.

2. A plan with clear targets that monitored data can be compared against.

3. An historical database of climatic and farm performance data.

4. A broad set of contingency plans and associated decision rules to determine the best option to implement for the existing conditions.

\section{ACKNOWLEDGEMENTS}

Firstly, the authors would like to thank our case farmers and their partners for all the time and effort they have put into this piece of research, it was much appreciated. We would also like to thank the Riverside Trust for the opportunity to undertake this research and in particular the help of Gareth Evans. Finally we would like to thank Chris Garland and Jane Murray of Baker and Associates for all their help with this project.

\section{REFERENCES}

Crawford, A.; McCall, D.; Mason, W.; Paine, M. 2007. Industry adaptation - challenges when building resilient farming systems. pp. 508-519. In: Meeting the Challenges for Pasture-Based Dairying. Proceedings of the 3rd Dairy Science Symposium, 18 -20 September 2007. Eds. Chapman, D.F.; Clark, D.A.; Macmillan, K.L.; Nation, D.P. National Dairy Alliance, Melbourne.

Denzin, K. 1989. The Research Act: A Theoretical Introduction to Sociological Methods. Third edition. McGraw-Hill, New York.

Dey, I. 1993. Qualitative Data Analysis: A User-friendly Guide for Social Scientists. Routledge, New York.

Gray, D.I. 2001. The tactical management processes used by pastoral-based dairy farmers: A multiple-case study of experts. Unpublished PhD Thesis. Massey University, Palmerston North.

Harvie, A.G. 1989. Post-drought reflections and the importance of decision making. Proceedings of the New Zealand Grassland Association 50: 123-126.

Hayman, J.M.; Munro, J.M. 1983. Silage for flushing ewes. Proceedings of the New Zealand Grassland Association 44: 196-202.

Kenny, S.; O'Brien, G. 2007. A climate change: Adapting systems to address complex problems, pp. 570-577. In: Meeting the Challenges for Pasture-Based Dairying. Proceedings of the 3rd Dairy Science Symposium. 18 - 20 September 2007. Eds. Chapman, D.F.; Clark, D.A.; Macmillan, K.L; Nation, D.P. National Dairy Alliance, Melbourne.

Kerr, P. 2000. 400 Plus: A Guide to Improved Lamb Growth for Farmers and Advisors. The New Zealand Sheep Council: Wellington.

Kinnell, D. 1993. Managing for risk on summer dry coastal hill country. Proceedings of the New Zealand Grassland Association 55: 51-52.

Martin, S. K. 1994. Risk perceptions and management responses to risk in pastoral farming in New Zealand. Proceedings of the New Zealand Society of Animal Production 54: 363-368.

Martin, S. 1996. Risk management strategies in New Zealand agriculture and horticulture. Review of Marketing and Agricultural Economics 64: 31-44.

McLaren, N. 1993. Profitability through matching feed 
supply to profitability. Proceedings of the New Zealand Grassland Association 55: 165-168.

McRae, A. 2003. Historical and practical aspects of profitability in commercial beef production systems. Proceedings of the New Zealand Grassland Association 65: 29-34.

Morris, S.T.; Kenyon, P.R. 2004. The effect of litter size and sward height on ewe and lamb performance. New Zealand Journal of Agricultural Research 47: 275286.

Miles, M.B.; Huberman, A.M. 1994. Qualitative Data
Analysis: An Expanded Source Book. Second edition. Sage Publications, Beverly Hills, CA.

Muir, P.D.; Wallace, G.J.; McCall, D.G.; Dodd, C.J. 1999. Effect of ewe milk production on profitability of dryland lamb production. Proceedings of the New Zealand Grassland Association 61: 101-105.

Rattray, P.V. 1983. Use of pasture silage as a summer supplement for ewes. Proceedings of the New Zealand Grassland Association 44: 188-195.

Yin, R.K. 2002. Application of Case Study Research. Second Edition. London: Sage Publications. 